\title{
二重空隙モデルを用いた地盤挙動に関する考察
}

\section{A STUDY ON THE ANALYSIS OF GROUND WITH DOUBLE POROSITY MODEL}

\author{
大西有三*・小林晃**.塩田卓央*** \\ By Yuzo OHNISHI, Akira KOBAYASHI and Takuo SHIOTA
}

\begin{abstract}
An idealized double porosity model is developed for the purpose of studying the coupled effects of flow in porous blocks and fractures as well as solid displacement in saturated-unsaturated medium.

Subsequently, Galerkin formulation is used for the finite element method to develop a new technique to investigate coupled hydraulic-mechanical behavior in the double porosity model reservoir.

The verifications are performed in comparison with an analytical solution of onedimensional consolidation problem and experimental results of unsteady flow in the sand box. Finally, a secondary compression is examined with this model, the environment of rock mass in Lugeon test is simulated, and two-dimensional consolidation problems in a saturated and saturated-unsaturated media are investigated with comparison with the single porosity model.
\end{abstract}

Keywoords: rock hydraulics, FEM, saturated-unsaturated flow, consolidation analysis

\section{1.はじめに}

土質ならびに岩盤工学の分野において，構造物の設 計・施工に浸透水の影響を考慮することは常識となって いる. しかし, 浸透水を単独でなく, 地盤の変形や破壊 とからめて相互作用を考慮のうえ, 総合的に検討を進め るという手順は最近になって本格化してきたものであ る.

土質地盤に対するこのような解析的研究は, Christian やSandhuによる圧密に対する研究をはじめ ${ }^{1,2)}$, 多 くの成果が発表されており, 近年では土の構成則に塑性 や粘性を考慮したモデルも開発されている.

一方, 対象を岩盤に移すと, その浸透挙動・変形挙動 については, ともに研究の歴史が浅く, 岩盤のモデル化 も含め百花僚乱の樣相を呈しているのが現状である.

岩盤内の浸透は, 亀裂の存在の仕方に大きく依存して おり, 複雑に連結した亀裂に沿って流れたり，あるいは 淀み域に拘束されつつ流れており, その解析手法として は多孔質連続体モデル, 亀裂ネットワークモデルなどが

* 正会員 Ph.D. 京都大学助教授 工学部交通土木工学 科 ( T606 京都市左京区吉田本町)

** 正会員 間組技術研究所 ( 7338 与野市本町西 4-17-23)

*** 工修 地域振興整備公団

（テ105 千代田区霞ヶ関 3-8-1 虎)門三井ヒル）

\section{考えられる。}

多孔質連続体モデルは，対象となる刍裂性岩盤を等価 な多孔質の連続体で置き換えるもので, 刍裂内の流れが 支配的な岩盤中の浸透挙動をいかに連続場の流れとして 評価するかが課題である.このような研究には, 小田ら によるクラックテンソル3)あるいは Long ら" ${ }^{4)}$ による透 水係数テンソルの評価手法などの研究がある.

亀裂ネットワークモデルは, 有限要素解析において, 亀裂の性状および幾何形状について十分な情報量がある ときに，亀裂部分に岩体とは異なる特性をもつジョイン 卜要素を用いて行うものである。このような手法には Noorishad $ら^{5)}$ や大西ら ${ }^{6}$ による研究がある.

さらに，上記の 2 つを組み合わせ，明確な大きな亀裂 をジョイント要素で, 細かい亀裂群を等価多孔体として ハイブリッド的に解析を行う手法も提案されている7).

岩盤の変形挙動に関する研究も上記の浸透流に関する ものと同様の手法が取られているが，その他に不連続部 を岩盤の挙動の支配的要因と考えた $\mathrm{RBSM}^{8)}$ や個別要 素法 ${ }^{91}$ のような極限解析的なものも多く発表されてい る.

本研究では亀裂のある岩盤内の浸透流を評価するため に, 二重空隙モデル (Double Porosity Model) を適用 した。これは 1960 年に Barenblatt ${ }^{10)}$ によって紹介され 


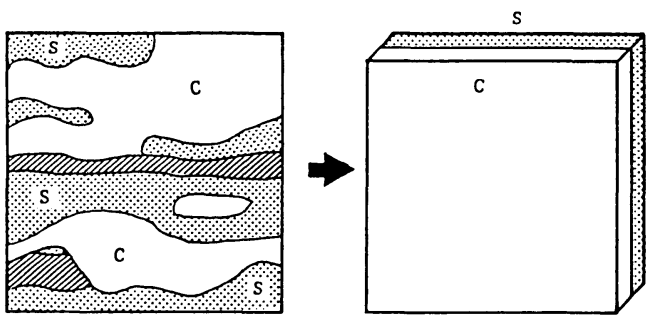

Fig. 1 Double porosity modeling.

たモデルであり，統計平均・体積平均を用いて亀裂性岩 盤を $2 つ$ 重なった仮想の連続体で表わすものである.

二重空隙モデルによる岩盤内の浸透についての研究 は, 先述の Barenblatt らのほか, Huyakorn ら ${ }^{11)}$ Warren ら ${ }^{12)}$ によって行われており，このモデルを用い た現場データの検討の多くは石油工学者によって行われ てきた。また，佐藤ら ${ }^{13)}$ は，二重空隙モデルを割れ目系 をもつ透水性ブロックの集合により模擬し，二重空隙性 を考慮した岩盤浸透流の抵抗則について実験を行い, 割 れ目幅が小さくなると, 岩盤全体の透水性における岩体 自体の透水性の影響が大きくなることを示した.

また, 変形を考慮した二重空隙モデルに関する研究は,

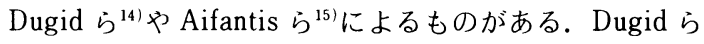
は, 飽和領域を対象とした方程式を導いたが，応力のつ り合いは片方の空隙場でのみ考えている. Aifantis らに よる研究は, 同様に飽和領域を対象とした方程式を用い ており, 地下水の流れと応力のつり合いの連成項の定数 の决定を Nur ら ${ }^{16)}$ が行った有効応力の定義を応用して 力学的な面から検討している.

本論では不飽和領域を表わすパラメーターを用いるこ とにより，解析領域を不飽和領域に拡張した。 また，応 力場については，流れのように岩体と亀裂に分けずに， 両方の空隙場を含めた連続場のつり合いを考えた. そし て地下水の流れと応力ーひずみ関係の間の相互作用を考 慮するため, 地下水流れの連続の式と応力のつり合い式 を連成した形で誘導した。

二重空隙モデルは先述のように, 貯油層岩盤を対象と して発展してきたモデルであるが，見方を変えれば応用 範囲がいろいろあり土質地盤にも適用できる．たとえば 砂層と粘土層の互層で各層が薄く三次元的にからみ合っ ており, 解析領域が広い場合には, 有限要素で細かく不 均一性を考慮する代わりに, 砂層と粘土層が重なった二 重空隙モデルとして解析することも可能である(Fig. 1).

本論では，新たに開発した飽和一不飽和領域における 変形を考慮した二重空隙モデルを用いて, 種々の地盤の 挙動について考察した。

\section{2. 二重空隙モデルの概念}

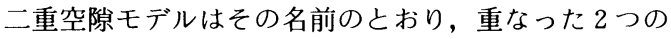
空隙場で流れ場を考える. すなわち, 空間の同一時点に $2 つ$ 水圧を設定し,それぞれについて連続の式を作る. この 2 つの水圧を $p_{1}, p_{2}$ とすると, たとえば対象が亀 裂性岩盤の場合, Fig. 2 のよう $p_{1}$ を岩体内の水圧, $p_{2}$ を亀裂内の水圧とみなすことができる. そして, 前 節で述べたハイブリッド法に対して，細かい亀裂集合体 内の水圧と, 大きな亀裂内の水圧を分離して取り扱うこ とができる.この 2 つ流れ場の透水性が異なるため同 一地点で水生差が生じ, 一方から他方への流体の移動が 発生する.たとえば, 岩体と亀裂で透水性を比べれば, 亀裂の方がかなり高い. したがって, 排水時の非定常の 段階では岩体内の水圧 $p_{1}$ は亀裂内の水圧 $p_{2}$ より大きく なり，岩体から亀裂へと流体の移動が起こる。

このように, 二重空隙モデルは解析対象場を 2 つの流 れ場に分けて方程式を立て, その方程式を互いに連成さ せたものである.むろん, 流れ場を 2 つ以上の多重空隙 モデルに設定することも可能である.

ここで明らかなように，二重空隙モデルは各空隙場の 相互作用を考慮することで, 不均一場を表現しているの で，このモデルによる解析は非定常過程において意味を もつことになる.

また二重空隙モデルでは同一時点に複数の水圧が存在 するが，このようなことは実際にはあり得ない. 二重空 隙モデルが数学モデルだといわれる由縁はここにある. したがって,このモデルでは実際現象との比較が難しい という久点をもつ. しかしながら, 水圧の測定結果がし ばしば連続にならないときがあることを考えると，実測 により得られた水圧の意味を改めて認識する必要性が, 逆にこのモデルから起こってくる.

さらに二重空隙モデルを適用する際, 注意を要する点 がある.それは等価連続体モデルにもいえることである

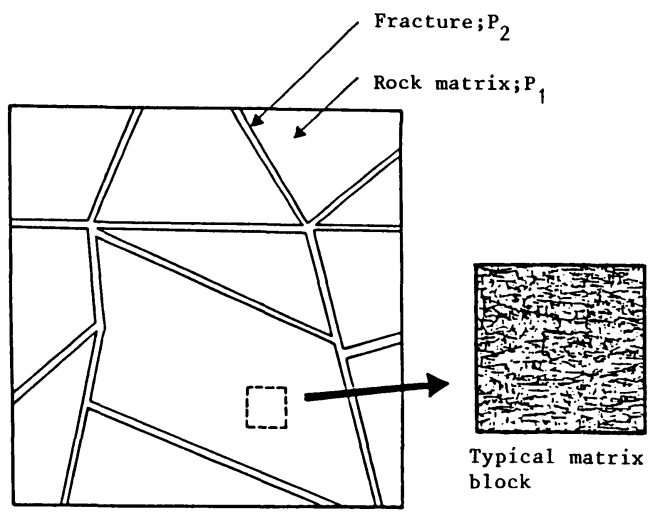

Fig. 2 Double porosity model of fractured rock mass. 


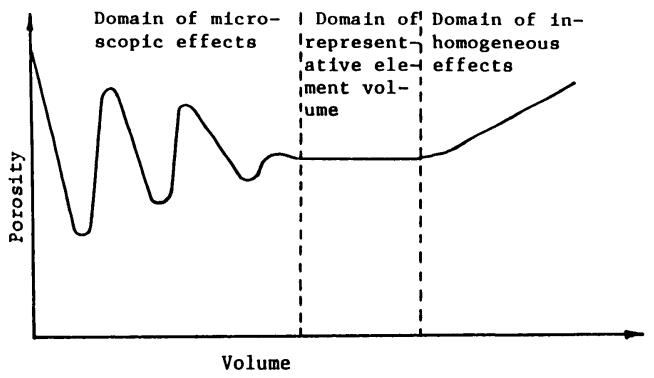

Fig. 3 Representative elementary volume.

が, 要素の大きさを決定する場合に適正規模, すなわち 代表的基準体積 (Representative Elementary Volume) を的確に決める必要があることである．たとえば亀裂性 岩盤の挙動を解析する場合, 要素内は一様であると考え るが, 要素が大きすぎる場合は一様性の仮定がくずれ, 小さすぎる場合もその部分の偏った性質しか表わさなく なる (Fig. 3). 一様性仮定の成立は連続体の解析では当 然必要なこととして受け止められてきたが, 二重空隙モ デルを用いて, 亀裂性岩盤のように不均一性と異方性の 卓越した場を解析するときには特に重要となる。

\section{3. 基本方程式}

本研究の基本方程式を導くにあたって，用いた主な仮 定を以下に示す.

1）地盤は等方弾性多孔質体とする.

2）土水中の流れは飽和-不飽和領域を対象とし, 両 空隙においてもダルシー則に従うものとする。

3) 二次元平面問題亡する.

4）流体はやや圧縮性，地盤構成粒子（固相）は非圧 縮性とする.

5）変形については地盤全体で考え, 変形に影響を及 ぼす水圧は，それぞれ第 1 と第 2 空隙の水圧に空隙 率と飽和度で重み付けしたもので表わせるものとす る.

6）不飽和領域においては第 1 空隙部分（たとえば岩 体部分）は土質地盤で用いられるような不飽和透水 特性曲線を用いて決定されるものとし, 第 2 空隙部 分 (たとえば亀裂部分) の流れは, 不飽和領域では 存在しないものとする.

（1）つり合い式

応力のつり合いは，先述のように第 1 ・第 2 空隙場の 両方を含めた解析対象場全体で考える，等方弾性体の全 応力に対するつり合い式は，すでに多くの研究によって 述べられているものとほぼ同じであり, 引張を正とし， 微小変形を仮定すると, 以下のようになる.

$$
\frac{\partial \sigma_{i j}^{0}}{\partial x_{j}}+F_{i}+G \frac{\partial^{2} u_{i}}{\partial x_{j} \partial x_{j}}+(\lambda+G) \frac{\partial^{2} u_{j}}{\partial x_{j} \partial x_{i}}-\alpha^{\prime} \frac{\partial p}{\partial x_{i}}=0
$$

ここで， $\sigma_{i j}^{0}$ は初期有効応力テンソル， $u_{i}$ は地盤骨格の 変位成分, $F$ は物体力, $\lambda, G$ は Lamé の定数である. この $\lambda, G$ は異なる弾性定数をもつ第 1 空隙場と第 2 空 隙場の両方を含めた場の挙動を表わすものであることに 注意を要する． $\alpha^{\prime}$ は水圧の有効応力への寄与率であり, 飽和土質地盤の場合には 1 となり有効応力の原理が成り 立つ.また $p$ は, 第 1 空隙内の水圧 $p_{1}$ と第 2 空隙内の 水圧 $p_{2}$ によって,

$$
p=\left(S_{r_{1}} n_{1} p_{1}+S_{r_{2}} n_{2} p_{2}\right) /\left(n_{1}+n_{2}\right) \text {. }
$$

と表わせるものと仮定する.ここで， $S_{r}, n$ はそれぞれ 飽和度, 空隙率を表わし, 添字 1,2 はそれぞれ第 1 , 第 2 空隙場を示す.この水圧の分配の仕方については, Aifantis (5) $^{15}$ のうに有効応力の定義から検討する方法 もあるが, その場合の $p_{1}, p_{2}$ の係数の值は今回の方法 による値とさほど変わらない結果となる.

また空隙率の定義は, $n_{1}$ を第 1 ・第 2 空隙場を含め た全体積中に占める第 1 空隙の体積, $n_{2}$ を同様に全体 積中に占める第 2 空隙の体積とする.

\section{-（2）連 続 式}

変形を考慮した二重空隙モデルを用いた地下水の連続 式を以下に説明する.

地盤の固相部分の質量保存式は以下のように書ける.

$$
-\frac{\partial}{\partial x_{i}}\left[\left(1-n_{1}-n_{2}\right) \rho_{s} v_{i s}\right]=\frac{\partial}{\partial t}\left[\left(1-n_{1}-n_{2}\right) \rho_{s}\right] \cdots
$$

ここに, $\rho_{s}$ は固相部分の密度, $v_{i s}$ は固相部分の変位速 度である．ここで，次の物質導関数を導入して，

$D / D t=\partial / \partial t+v_{i s} \partial / \partial x_{i}$

また, $D \rho_{s} / D t=0$ と仮定すると, 式（3）は次式のよ うになる。

$$
D n_{1} / D t+D n_{2} / D t=\left(1-n_{1}-n_{2}\right) \partial v_{i s} / \partial x_{i}
$$

次に, 地盤の第 1 空隙内の流体の連続式を考える. $V_{i 1}$ を第 1 空隙中のダルシー流速とする. ダルシー流速 は, 静止した地盤中の水の流れに対して成り立つので, $V_{i 1}=n_{1} S_{r 1}\left(V_{i \Omega 1}-V_{i s}\right)$ と表わせる.ここで， $V_{i \Omega 1}$ は第 1 空隙内の流体の実流速を示す. よって第 1 空隙内の流れ の連続式は次のようになる。

$$
-\frac{\partial}{\partial x_{i}}\left(n_{1} S_{r 1} v_{i \Omega 1} \rho_{f}\right)-\Gamma=\frac{\partial}{\partial t}\left(n_{1} S_{r_{1}} \rho_{f}\right)
$$

ここに， $\Gamma$ は，単位体積当たりの第 1 空隙から第 2 空 隙へ移動する流体流量である. 物質導関数の定義と上述 のダルシー流速 $V_{i}$ を導入すると式 $(6)$ は以下となる.

$$
\begin{aligned}
-\frac{\partial}{\partial x_{i}}\left(\rho_{f} v_{i 1}\right)= & n_{1} S_{r 1} \frac{D \rho_{f}}{D t}+\rho_{f} n_{1} \frac{D S_{r 1}}{D t}+\rho_{f} S_{r 1} \frac{D n_{1}}{D t} \\
& +\rho_{f} n_{1} S_{r 1} \frac{\partial v_{i s}}{\partial x_{i}}+\Gamma \cdots \cdots \cdots \cdots \cdots \cdots(7
\end{aligned}
$$

式（5）と式（7）を組み合わせて, 式（7）の右辺 
第 1 項に流体の圧縮性の関係式 $d \rho_{f}=\rho_{\rho \circ} \beta d p$ を用いると 以下を得る.

$$
\begin{aligned}
-\frac{\partial}{\partial x_{i}}\left(\rho_{f} v_{i 1}\right)= & n_{1} S_{r 1} \rho_{f 0} \beta \frac{D p_{1}}{D t}+\rho_{f} n_{1} \frac{D S_{r 1}}{D t} \\
& +\rho_{f} S_{r_{1}}\left(1-n_{2}\right) \frac{\partial v_{i s}}{\partial x_{i}}-\rho_{f} S_{r 1} \frac{D n_{2}}{D t}+\Gamma
\end{aligned}
$$

ただし, $\rho_{f}$ は流体の密度, $\rho_{\text {s }}$ は標準状態での流体の密度, $\beta$ は流体の圧縮率を表わす。一方， $n_{2}$ の定義は次のよ うに書ける。

$$
n_{2}=V_{2} / V
$$

ここで, $V_{2}$ は第 2 空隙の体積， $V$ は領域全体の体積で ある. 式（9）を時間で微分すると，以下となる。

$$
D n_{2} / D t=\left(D V_{2} / D t-n_{2} D V / D t\right) / V
$$

ここで,

$$
V=V_{1}+V_{2}+V_{s}
$$

$V_{1}$ は第 1 空隙の体積， $V_{s}$ は固相部分の体積である. 固 相部分は非圧縮性であると仮定すると上式より以下を得 る.

$$
D V / D t=D V_{1} / D t+D V_{2} / D t
$$

式（10）に式（12）を代入することで次式が得られる.

$D n_{2} / D t=\left\{\left(1-n_{2}\right) D V_{2} / D t-n_{2} D V_{1} / D t\right\} / V$

また，流体の圧縮性の定義

$$
\begin{aligned}
& -\beta n_{1} S_{r_{1}} V D p_{1} / D t=D V_{1} / D t \\
& -\beta n_{2} S_{r_{2}} V D p_{2} / D t=D V_{2} / D t
\end{aligned}
$$

を式（13）に導入すると次式が得られる。

$$
\begin{aligned}
D n_{2} / D t= & -\left(1-n_{2}\right) \beta n_{2} S_{r_{2}} D p_{2} / D t \\
& +n_{2} \beta n_{1} S_{r_{1}} D p_{2} / D t \cdots \cdots . .
\end{aligned}
$$

式（15）を式（8）の右辺第 4 項に代入することで次式 が求められる.

$$
\begin{aligned}
& -\frac{\partial v_{i 1}}{\partial x_{i}}=n_{1} S_{r_{1}} \beta\left(1-n_{2} S_{r_{1}}\right) \frac{\partial p_{1}}{\partial t} \\
& +n_{2}\left(1-n_{2}\right) S_{r_{1}} S_{r_{2}} \beta \frac{\partial p_{2}}{\partial t}+n_{1} \frac{\partial S_{r 1}}{\partial t} \\
& +\left(1-n_{2}\right) S_{r_{1}} \frac{\partial v_{t s}}{\partial x_{i}}+\frac{\Gamma}{\rho_{s}}
\end{aligned}
$$

ここに，流体はやや圧縮性で $D p_{1} / D t \simeq \partial p_{1} / \partial t, D p_{2} /$ $D t \simeq \partial p_{2} / \partial t$ とし $\rho_{f 0}=\rho_{f}, \quad D S_{r 1} / D t \simeq \partial S_{r 1} / \partial t$ と仮定 した.

次に，次式が成り立つと仮定する.

$$
n_{1} \partial S_{r_{1}} / \partial t \simeq \partial n_{1} S_{r_{1}} / \partial t=\partial \theta_{1} / \partial t=\partial \theta_{1} / \partial p_{1} \cdot \partial p_{1} / \partial t
$$

\section{ここで $\theta_{1}$ は第 1 空隙場の体積含水率である.}

第 2 空隙に対する流体の連続式は同椂の方法を使って 導かれ, 結果は以下で与えられる.

$$
-\frac{\partial v_{i 2}}{\partial x_{i}}=n_{1}\left(1-n_{1}\right) S_{r_{1}} S_{r 2} \beta \frac{\partial p_{1}}{\partial t}
$$

$$
\begin{aligned}
& +n_{2} S_{r_{2}} \beta\left(1-n_{1} S_{r_{2}}\right) \frac{\partial p_{2}}{\partial t}+\frac{\partial \theta_{1}}{\partial p_{1}} \frac{\partial p_{1}}{\partial t} \\
& +\left(1-n_{1}\right) S_{r 2} \frac{\partial v_{t s}}{\partial x_{i}}-\frac{\Gamma}{\rho_{f}}
\end{aligned}
$$

$2 つ の$ 流れの方程式の最終の形を得るために，次のダル シー則を用いる.

$$
\left.\begin{array}{l}
v_{i 1}=-\frac{k_{1 i j}}{\mu}\left(\frac{\partial p_{1}}{\partial x_{j}}+\rho_{s} g_{j}\right) \\
v_{i 2}=-\frac{k_{2 i j}}{\mu}\left(\frac{\partial p_{2}}{\partial x_{j}}+\rho_{s} g_{j}\right)
\end{array}\right\}
$$

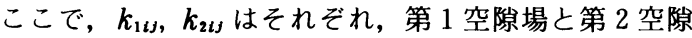
場の固有透水係数テンソル, $\mu$ は動粘性係数, $g$ は重力 加速度ベクトルである. よって, 求める流れの方程式は 以下のようになる。

$$
\begin{aligned}
& \frac{\partial}{\partial x_{i}}\left[\frac{k_{m i j}}{\mu}\left(\frac{\partial p_{m}}{\partial x_{j}}+\rho_{s} g_{j}\right)\right]=n_{m} S_{r m} \beta\left(1-n_{\hat{m}} S_{r m}\right) \frac{\partial p_{m}}{\partial t} \\
& \quad+n_{\hat{m}}\left(1-n_{\hat{m}}\right) S_{r m} S_{r \hat{m}} \beta \frac{\partial p_{\hat{m}}}{\partial t}+\frac{\partial \theta_{m}}{\partial p_{m}} \frac{\partial p_{m}}{\partial t} \\
& \quad+\left(1-n_{\hat{m}}\right) S_{r m} \frac{\partial v_{i s}}{\partial x_{i}} \pm \frac{\Gamma}{\rho_{s}} \quad \begin{cases}\text { if } & m=1, \hat{m}=2 \\
\text { if } & m=2, \hat{m}=1\end{cases}
\end{aligned}
$$

\section{（3）漏出項 $\Gamma$}

Barenbratt ${ }^{10)}$ のモデルでは, 第 1 空隙から第 2 空隙へ の漏出量 $\Gamma$ を求めるための定数を次元解析により求め ており，その物理的意味は明確ではない。また彼らのモ デルでは定常状態の漏出しか表わせない.

Barenbratt らの手法に代わるものとして，非定常な

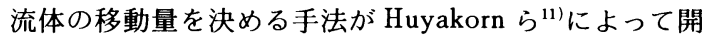
発されている.この手法では，第 1 空隙場を直方体ある いはそれと同じ大きさの球として理想化する．そして第 1 空隙場から第 2 空隙場への流れは，一次元の非定常流 れ方程式を用いて差分法によって求められる.

また，Dugid ら ${ }^{14)}$ は非定常な漏出項を一次元の熱伝導 方程式の解析解を用いて表わすことを武みている．彼ら は非定常な挙動を考虑した場合と定常な漏出のみを扱っ た場合の違いについて検討し，その結果，両者の違いは わずかであり，定常状態のモデルを用いても精度は十分 に確保されることを示した。

彼らによる非定常項を省略した定常状態の漏出項は以 下のようである。

$$
\Gamma=\frac{k_{1}}{\mu} \frac{4 n_{2} \rho_{f}}{\pi C l}\left(p_{1}-p_{2}\right)
$$

ここで, $l$ は第 1 空隙場の亀裂長さの半分 (Matrix characteristic length), $C$ は第 1 空隙場の亀裂断面の短 軸の半分 (Void aperture) である.

本研究においてはこの式を漏出項 $\Gamma$ に用いることに した.

\section{（4）初期・境界条件}


上述の方程式を解くには次の初期条件，境界条件が必 要である.

初期条件；

$$
\left.\begin{array}{l}
u_{i}\left(x_{1}, x_{2}, t\right)=u_{i}^{0}\left(x_{1}, x_{2}, 0\right) \\
p_{1}\left(x_{1}, x_{2}, t\right)=p_{1}^{0}\left(x_{1}, x_{2}, 0\right) \\
p_{2}\left(x_{1}, x_{2}, t\right)=p_{2}^{0}\left(x_{1}, x_{2}, 0\right)
\end{array}\right\}
$$

境界条件;

$$
\begin{gathered}
u_{i}\left(x_{1}, x_{2}, t\right)=\hat{u}_{i}\left(x_{1}, x_{2}, t\right) \\
\tau_{i j}\left(x_{1}, x_{2}, t\right) n_{j}=\hat{S}_{i}\left(x_{1}, x_{2}, t\right) \\
p_{m}\left(x_{1}, x_{2}, t\right)=\hat{p}_{m}\left(x_{1}, x_{2}, t\right) \\
\left\{\frac{k_{m i j}}{\mu}\left(\frac{\partial p_{m}}{\partial x_{j}}+\rho_{f} g_{j}\right)\right\} n_{j}=-\hat{Q}\left(x_{1}, x_{2}, t\right) \\
m=1,2
\end{gathered}
$$

\section{4. 有限要素定式化}

以上の方程式を Galerkin 法を用いて離散化した。本 研究では要素として 4 節点 4 角形要素を用いた。時間微 分の項に加速係数 $\alpha$ を用いて差分表示し, 変位を増分 表示した結果を以下に示す.

$$
\begin{aligned}
& \left.\left[\begin{array}{cccc}
K_{I J}^{x} & L_{I J}^{x} & C_{I J}^{x} & G_{I J}^{x} \\
L_{I J}^{x T} & K_{I J}^{y} & C_{I J}^{y} & G_{I J}^{y} \\
E_{I J}^{1 x} & E_{I J}^{1 y} & \alpha A_{I J}^{1}+B_{I J}^{1} & \alpha F_{I J}^{1}+D_{I J}^{1} \\
E_{I J}^{2 x} & E_{I J}^{2 y} & \alpha F_{I J}^{2}+D_{I J}^{2} & \alpha A_{I J}^{2}+B_{I J}^{2}
\end{array}\right] \mid \begin{array}{c}
\Delta u_{x} \\
\Delta u_{y} \\
p_{1} \\
p_{2}
\end{array}\right) \\
& =\left|\begin{array}{l}
\Delta F^{x}+C_{I J}^{x} p_{1}^{t}+G_{I J}^{x} p_{2}^{t} \\
\Delta F^{y}+C_{I J}^{y} p_{1}^{t}+G_{I J}^{y} p_{2}^{t} \\
Q_{1}+\left\{(\alpha-1) A_{I J}^{1}+B_{I J}^{1} p_{1}^{t}+\left\{(\alpha-1) F_{I J}^{1}+D_{I J}^{1}\right\} p_{2}^{t}\right. \\
Q_{2}+\left\{(a-1) F_{I J}^{2}+D_{I J}^{2}\right\} p_{1}^{t}+\left\{(\alpha-1) A_{I J}^{2}+B_{I J}^{2}\right\} p_{2}^{t}
\end{array}\right| \\
& K_{I J}^{i}=\int_{v_{e}}\left\{(\lambda+2 G) N_{l, i} N_{J, i}+G N_{I, \imath} N_{J, i}\right\} d V_{e} \\
& L_{I J}^{i}=\int_{V_{e}}\left\{\lambda N_{I, i} N_{J, i}+G N_{I, \imath} N_{I, i}\right\} d V_{e} \\
& C_{I J}^{i}=-\int_{V_{e}} \alpha^{\prime} S_{r 1} n_{1} /\left(n_{1}+n_{2}\right) \cdot N_{I, i} N_{J} d V_{e} \\
& G_{I J}^{i}=-\int_{V_{e}} \alpha^{\prime} S_{r 2} n_{2} /\left(n_{1}+n_{2}\right) \cdot N_{l, i} N_{J} d V_{e} \\
& E_{I J}^{m i}=\int_{v_{e}}\left(1-n_{\hat{m}}\right) S_{r m} N_{I} N_{J, i} d V_{e} \\
& A_{I J}^{m}=\int_{V_{e}} \Delta t\left\{\frac{k_{m i j}}{\mu} N_{t, i} N_{J, j}+\frac{\Gamma}{\rho_{f}} N_{I} N_{J}\right\} d V_{e} \\
& B_{I J}^{m}=\int_{v_{e}}\left\{n_{m} S_{r m} \beta\left(1-n_{\hat{m}} S_{r m}\right)+\frac{\partial \theta_{m}}{\partial p_{m}}\right\} N_{I} N_{J} d V_{e} \\
& F_{I J}^{m}=(-1)^{m-1} \int_{v_{e}} \Delta t \frac{\Gamma}{\rho_{f}} N_{I} N_{J} d V_{e} \\
& D_{I J}^{m}=\int_{v_{e}} n_{\hat{m}}\left(1-n_{\hat{m}}\right) S_{r m} S_{r \hat{m}} \beta N_{I} N_{J} d V_{e} \\
& \left\{\begin{array} { l } 
{ \hat { m } = 2 , \text { if } m = 1 } \\
{ \hat { m } = 1 , \text { if } m = 2 }
\end{array} \quad \left\{\begin{array}{l}
\hat{i}=x, \text { if } i=y \\
\hat{i}=y, \text { if } i=x
\end{array}\right.\right.
\end{aligned}
$$

式（24）を初期条件式（22），および境界条件式 (23) のもとで, 未知数 $\left(\Delta u_{i}^{t+\Delta t}, P_{1}^{t+\Delta t}, P_{2}^{t+\Delta t}\right)$ について解くこ
とにより，応力，浸透の相互作用を知ることができる. 変位は, 初期条件に各時間ステップで計算される変位増 分を足し合わせていくことで，その時刻までの変位 $u_{i}^{t}$ を計算する. 解析の初期においては初期条件, 境界条件 から式 (24) の右辺のベクトルが定められる. それ以降 は常に直前の時間ステップの $\left(u_{i}^{t}, P_{1}^{t}, P_{2}^{t}\right)$ を用いて右辺 のベクトルを作り，式 (24) の行列方程式を解く.

また，透水係数のサクションの依存性が含まれている ため, 問題は非線形となるので, 各時間ステップにおい て繰り返し計算をする.

\section{5. 解 析 例}

以上の手法により開発したプログラムを用いていくつ かの例題を解析した。 また, 今回の解析では便宜上, 有 効応力の原理が成り立つものと仮定し， $\alpha^{\prime}=1$ とした.

\section{（1）検 証例題}

まず，検証例題として一次元圧密問題を解析し，Terzaghi の理論解と比較した (Fig. 4). その結果, 経時変 化および最終沈下量ともきわめてよい一致を示した. そ の際, 第 2 空隙内の流体および第 1 空隙から第 2 空隙へ 漏出する流体は流れないようにした。 そして載荷直後は 第 1 空隙内の流体のみで荷重を受け持ち, 有効応力の増 加は第 1 空隙内の流体の流れによって起こるものとして 解析を行った。 また飽和一不飽和浸透流問題も第 2 空隙 の水圧と変位を拘束して解析し, 赤井ら ${ }^{17)}$ の行った実験 結果と比較した結果, よい一致をみた（Fig.5). 以上に

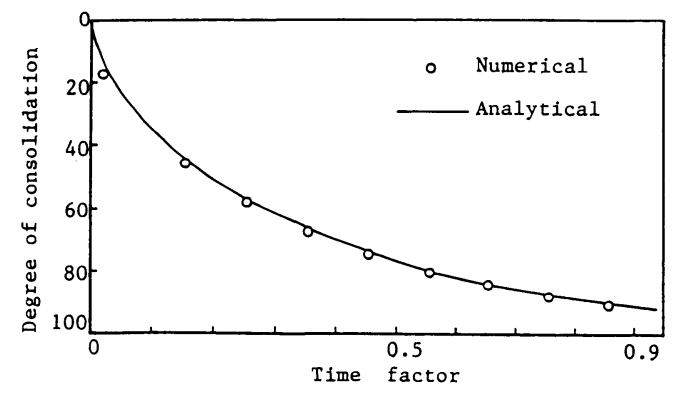

Fig. 4 Comparison of analytical solution with numerical one.

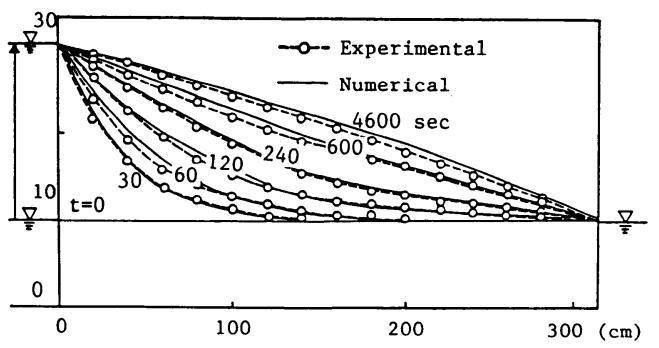

Fig. 5 Comparison of experimental results with numerical ones. 
より本コードの応力-浸透連成問題に対する基本機能は 信頼できるものと思われる.

\section{（2）二次圧密問題}

検証例題では Terzaghi の圧密理論と比較したが，実 際現象では Terzaghi の圧密理論による最終沈下量に 至っても，なお圧密が継続する場合がある．このような 二次圧密現象の解析には, 粘弾性解析を用いてクリープ 挙動として扱う場合が多い。しかし, 粘土粒子中の小孔 をミクロポア，粒子間の空隙部分をマクロポアとして区 別し, Fig. 6 のように一次圧密中の変形は主にマクロポ アの排水に, 二次圧密域の変形はミクロポアの排水に依 存して起こるとする説がある ${ }^{18)}$.ここでは, 二重空隙モ デルを用いて，このミクロ・マクロポア排水説による二 次圧密現象の説明を試みた。

つまり, 第 1 空隙をミクロポアとみなし, 第 2 空隙を マクロポアと考えてそれぞれ異なる透水性を設定した。

Fig. 7 に示す一次元有限要素メッシュと境界条件を用 い，均質な飽和粘土を対象として，上端面に荷重が作用 した場合について解析を行った。解析に用いた材料定数 を Table 1 に示す.

Fig. 8 に, 圧密沈下の経時変化を示す. ミクロポアか らの排水を考えないモデルを一重空隙モデル, ミクロポ アからの排水もマクロポアからの排水も両方考慮するモ デルを二重空隙モデルとよんで区別する．二重空隙モデ ルの計算結果 (点線) と一重空隙モデルの計算結果（実 線）を比較すると，第 1 空隙部（ミクロポア）から第 2 空隙部（マクロポア）への流体の流入による圧密沈下の 時間遅れが二重空隙モデルを用いた解析で起こってい る.しかし, 最終沈下量は両モデルとも同じである.こ れは, 弾性定数が両モデルとも同じであり, 二重空隙モ デルのミクロポアを構成する第 1 空隙場の弾性定数につ いての考慮が全くないためである.ここで Fig.9 のよう に, ミクロポアを構成する第 1 空隙部の変形とマクロポ アを構成する第 2 空隙部の変形を考慮して, 次式のよう な地盤全体の応力のつり合いを考える.

$$
\left\{C_{1} C_{2} /\left(C_{1}+C_{2}\right) \cdot \varepsilon-\left(C_{1}^{-1}+C_{2}^{-1}\right)\left(C_{1}^{-1} p_{1}+C_{2}^{-1} p_{2}\right)=\sigma\right.
$$

ここで, $C_{1}$ は第 1 空隙場の弾性定数, $C_{2}$ は第 2 空隙 場の弾性定数である. $C_{2}$ は土の骨格構造により決まる 弾性定数であり,これは Terzaghi の理論同様, 一定と 仮定する. $C_{1}$ はミクロポアからの排水が進むにつれ, 固くなることが予想されるので,ここでは, 指数関数的 に第 1 空隙場のヤング率が次式のように増加するものと 仮定した。

$$
E_{1}=E_{10} \exp \left(\Delta p_{1}^{0}-\Delta p_{1}\right) \text {. }
$$

ここで $\Delta p_{1}^{0}$ は載荷直後の間隙水圧で, この場合 $5 \mathrm{tf} / \mathrm{m}^{2}$ である. $\Delta p_{1}$ は第 1 空隙部のその時点における過剩間
Table 1 Data used in secondary compression analysis.

\begin{tabular}{ll}
\hline Properties & Values \\
\hline Permeability of micro pore & $1.0 \times 10^{-12} \mathrm{~m} / \mathrm{s}$ \\
Porosity of micro pore & 0.2 \\
Permeability of macro pore & $1.0 \times 10^{-9} \mathrm{~m} / \mathrm{s}$ \\
Porosity of macro pore & 0.5 \\
Young's modulus & $100 \mathrm{tf} / \mathrm{m}^{2}$ \\
Poisson's ratio & 0.3 \\
Void apeture & $0.025 \mathrm{~m}$ \\
Matrix characteristic length & $0.015 \mathrm{~m}$ \\
\hline
\end{tabular}

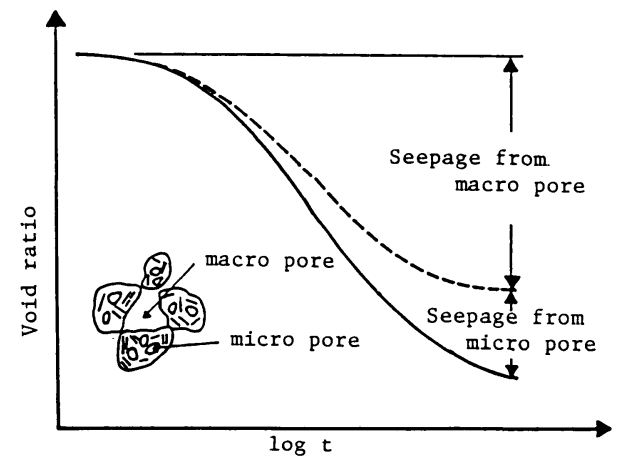

Fig. 6 Schematic compression-time curve.
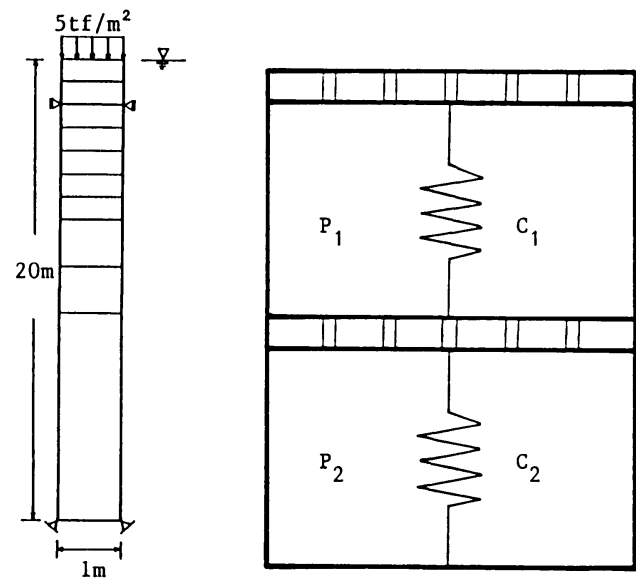

Fig. 7 Finite element model.

Fig. 9 Mechanical analogue.

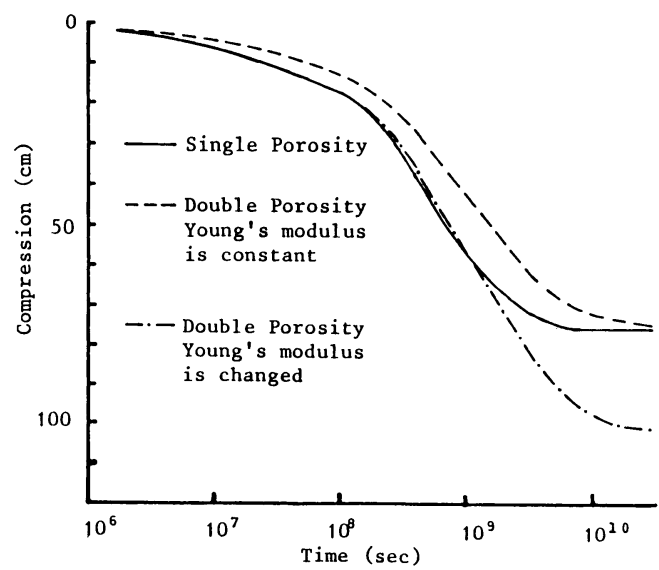

Fig. 8 Compression-time curve. 
隙水圧である.そして, 式 (25) より全体のヤング率を $E=E_{1} E_{2} /\left(E_{1}+E_{2}\right)$ として計算を行った.

第 1 ，第 2 空隙場とも初期のヤング率 $E_{0}$ を $100 \mathrm{tf} / \mathrm{m}^{2}$ として計算した結果を Fig. 8 に一点鎖線で示す.これに よると, 上記のような仮定を用いた結果は, 二次圧密を 定性的に表現しているといえる. また, 王密の進行とと もに，ミクロポアの空陌率が低下するので，それを考慮 した透水性の変化も考慮すると, Fig. 8 の結果（一点鎖 線）は終端での沈下速度が遅くなり，さらに実状と一致 する傾向を示すものと思われる.

このように，二次圧密をミクロポアからの排水による という説を用いて説明するためには，ミクロポアをもつ ペッド部分の変形も考慮した力学的定数を設定する必要 がある.このような定数の設定法については, 今回は式

（26）のような非線形性を用いたが，これは実証されて おらず，今後の検討が必要である.

(3) ルジオンテスト

前節では，二重空隙モデルを間隙水場と土粒子集合体 (ペッド) 内の流体場の 2 つの重なった連続体を用いて 二次圧密の解析を行った。しかし，二重空隙モデルは元 来岩盤を対象にして発展してきたものである．ここでは 従来のように亀裂場と岩体場の 2 つ連続体を用いてル ジオンテストのシミュレーションを行い岩盤内の水圧伝 播挙動について考察する。

有限要素メッシュはFig. 10 のように設定した. 解析 に用いた材料定数を Table 2 に示す．境界条件は，変位
境界として上下端は $x$ 方向の変位のみ, 左端は $y$ 方向 の変位のみスライドとし, 右端については変位固定とし た. そして水理境界として左端中央部に注入圧 $p_{1}=p_{2}$ $=10 \mathrm{kgf} / \mathrm{cm}^{2}$ を作用させ, 残りの端部は不透水とした. 地下水面は上端に設定し, 全領域で飽和となるようにし た.

Table 2 Data used for analysis of Lugeon test.

\begin{tabular}{ll}
\hline Properties & Values \\
\hline Permeability of rock matrix & $1.0 \times 10^{-11} \mathrm{~m} / \mathrm{s}$ \\
Porosity of rock matrix & 0.2 \\
Permeability of fracture & $1.0 \times 10^{-4} \mathrm{~m} / \mathrm{s}$ \\
Porosity of fracture & 0.05 \\
Young's modulus & $1.0 \times 10^{4} \mathrm{tf} / \mathrm{m}^{2}$ \\
Poisson's ratio & 0.3 \\
Fracture aperture & $0.001 \mathrm{~m}$ \\
Matrix characteristic length & $0.5 \mathrm{~m}$ \\
\hline
\end{tabular}

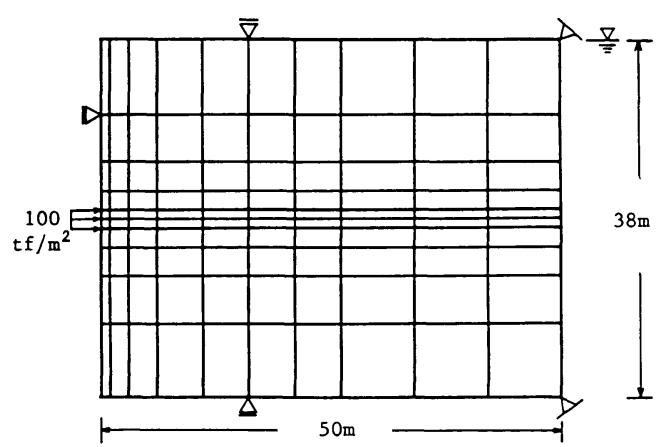

Fig. 10 Finite element model.

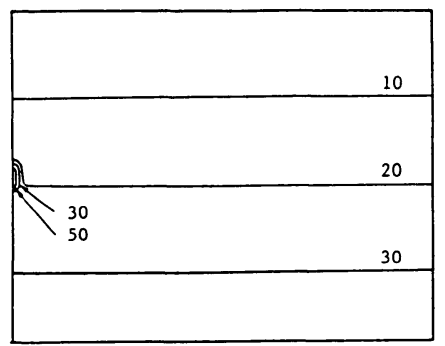

$\mathrm{t}=1.5 \mathrm{sec}$

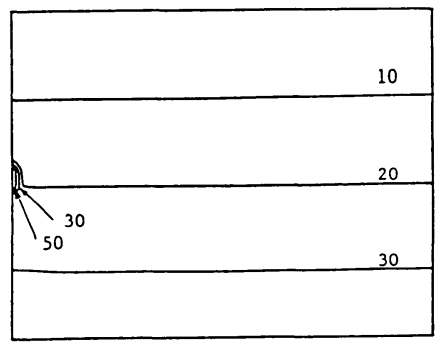

$t=1.5 \mathrm{sec}$

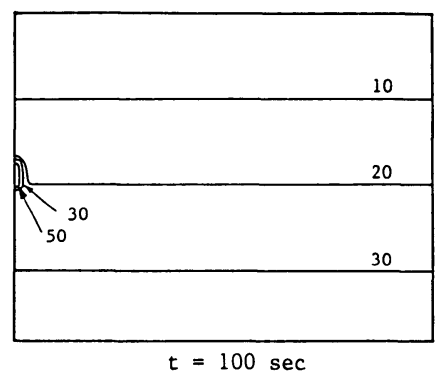

a) Rock matrix

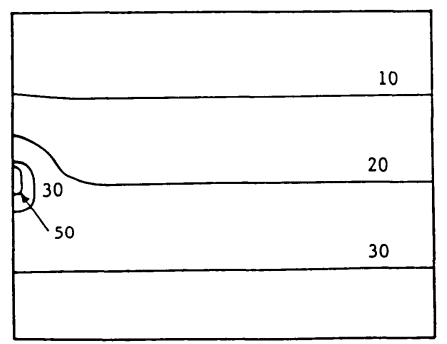

$t=100 \mathrm{sec}$

b) Fracture
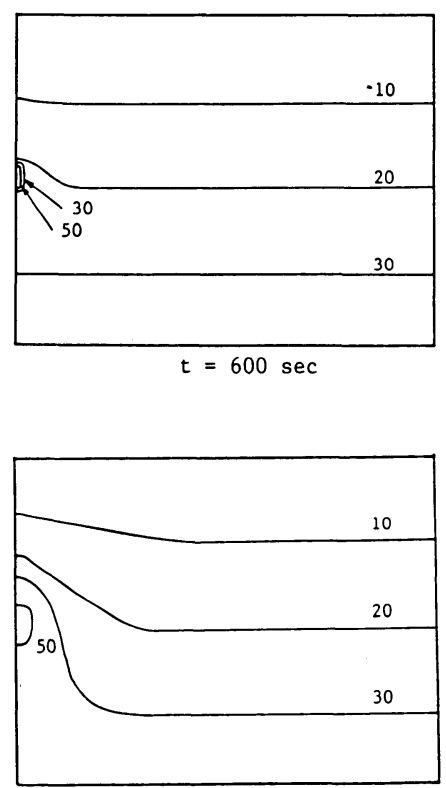

$t=600 \mathrm{sec}$

Fig. 11 Distribution of pressure head as a function of time $\left(t \mathrm{t} / \mathrm{m}^{2}\right)$. 
圧力伝播経過をFig.11 a),b）に示す．亀裂の透水係 数が $1.0 \times 10^{-4} \mathrm{~m} / \mathrm{s}$, 岩体の透水係数が $1.0 \times 10^{-11} \mathrm{~m} / \mathrm{s}$ と岩体の透水性が亀裂の透水性に比べてかなり小さいた めに，岩体中は玨力が非常に伝播しにくいことがよく表 現されている。，一方，亀裂の方は圧力が速く伝播してい く様子がわかる.

このように, 亀裂内と岩体内の水圧が不連続な状況が シミュレーションできており，これは既往の連続体や ジョイント要素を用いた解析では不可能なことであっ た。

実際現象においても亀裂性岩盤でのルジオンテストで は，注入水は亀裂を主に流れるため，同じような珐力伝 播過程を取るものと想像される.

また，今回は透水係数の異方性を考虑していないが, 亀裂場の異方性を考虑した解析を行えば，さらに実現象 に近いシミュレーションが可能であろう。

\section{(4) 二次元圧密浸透問題}

次に, Fig. 12 に示すモデルを用い，自由水面が存在 する場合の検討として二次元圧密の問題の解析を行っ た. 解析ケースは地下水面が地表面に一致した飽和状態 と地表面から $5 \mathrm{~m}$ の位置にある飽和-不飽和状態の 2 ケースで，それぞれ図のような外荷重が作用した場合に ついて解析を行った．解析に用いた材料定数を Table 3 に示す.ここでは5. ( 2 ) の二次圧密の解析のような弾 性定数の変化は考慮せず,一定とする. したがって, 応 力・変形挙動は線形弾性的であり, 二次圧密現象は現わ れない.この二重空隙モデルによる解析では，第 1 空隙 内の水の流れと，第 2 空隙場への漏水の影響による有効 応力の変化の仕方が従来の圧密モデルと異なる.

変位境界は, 下端は $x$ 方向のみ, 左右端は $y$ 方向の み変位を許し, 水理境界として左右端, 下端は不透水と し，飽和一不飽和解析の場合は地表面も不透水とした。

比較のために, 間隙水王には 1 次, 変位には 2 次のア イソパラメトリック要素を用いた Sandhu 型の圧密モデ ル (一重空隙モデル $)^{19)}$ による解析結果を合わせ示した.

Fig. 13 はA点における地表面の沈下量経時変化を示 している．二重空隙モデルを用いた計算結果は5. ( 2 ) の解析例 (点線) と同様に一重空隙モデルに比べて時間

Table 3 Data used for two-dimensional consolidation problem.

\begin{tabular}{ll}
\hline Properties & Values \\
\hline Permeability of primary porosity & $1.0 \times 10^{-12} \mathrm{~m} / \mathrm{s}$ \\
Porosity of primary porosity & 0.2 \\
Permeability of secondary porosity & $1.0 \times 10^{-9} \mathrm{~m} / \mathrm{s}$ \\
Porosity of secondary porosity & 0.5 \\
Young's modulus & $100 \mathrm{tf} / \mathrm{m}^{2}$ \\
Poisson's ratio & 0.33 \\
Void apeture & $0.02 \mathrm{~m}$ \\
Matrix characteristic length & $0.05 \mathrm{~m}$ \\
\hline
\end{tabular}

的な遅れがみられる，また不飽和部が存在する場合，載 荷初期の沈下量は飽和領域のみの結果よりも大きいが,

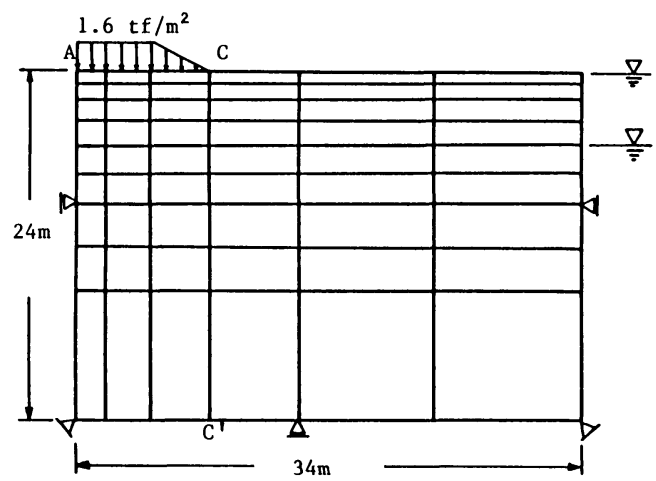

Fig. 12 Finite element model.

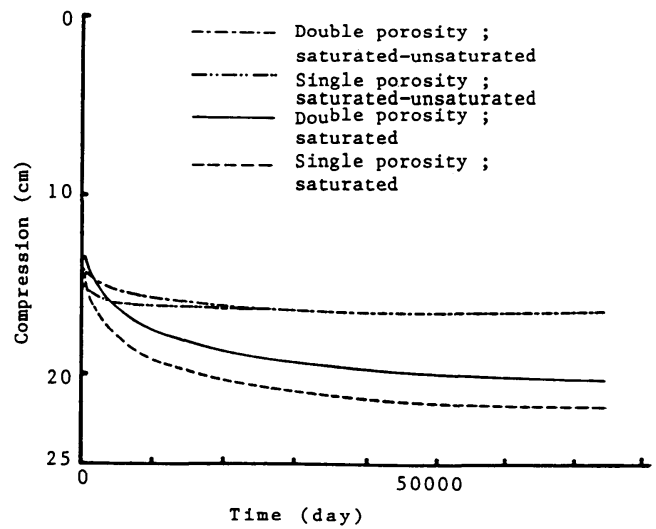

Fig. 13 Compression-time curve at point A.

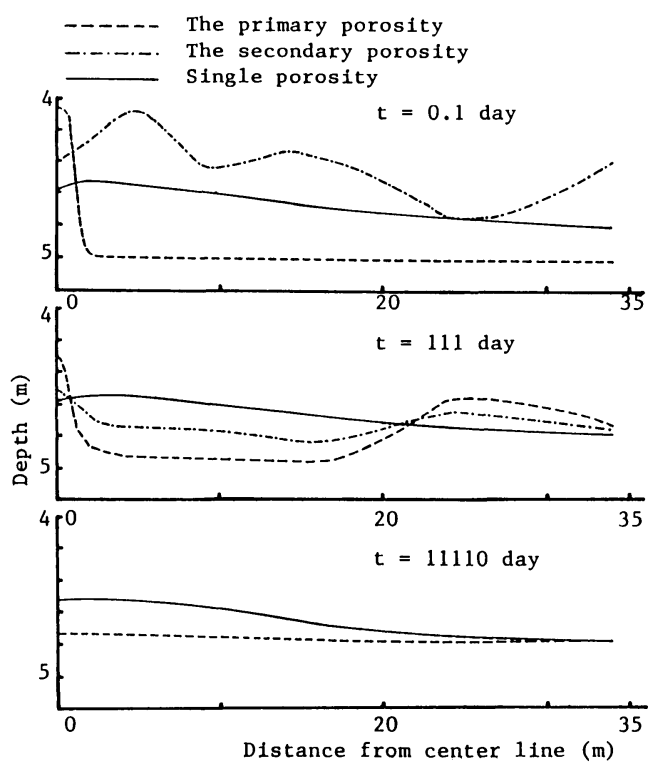

Fig. 14 Ground water tables as a function of time. 


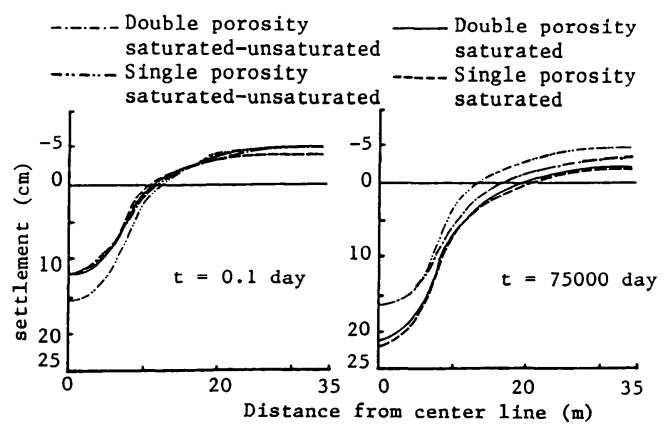

Fig. 15 Settlement as a function of distance from center line.

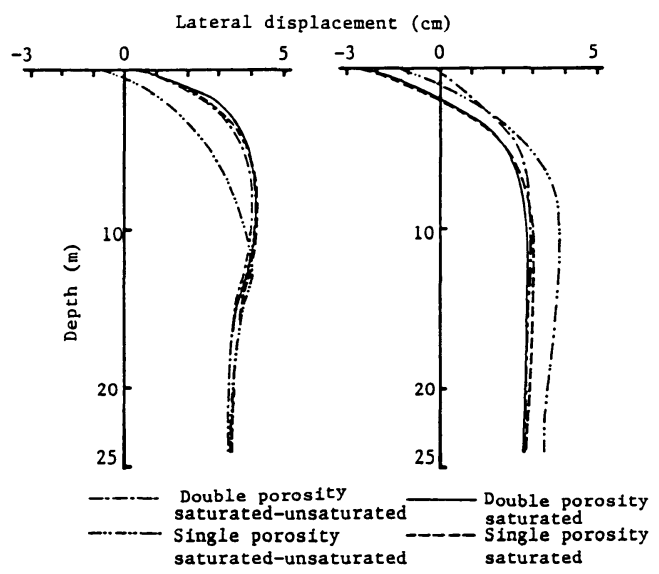

Fig. 16 Lateral displacement as a function of depth.

圧密による沈下は早めに終了し最終沈下量は小さくなる 傾向がみられる．これは載荷部が不飽和であるため圧密 による沈下は少なく，瞬時に起こる弾性的な沈下の影響 が大きいためであろう.

Fig. 14 は飽和-不飽和状態の地下水面分布の経時変化 図である，一重空隙モデルでは解析時間を通じてあまり 変化はしないが, 二重空隙モデルでは載荷初期では透水 係数の小さいペッド部（第 1 空腙）の水圧が載荷中央部 で高くなり，それ以外の所では透水性の大きい間隙水場 （第 2 空隙）の方が大きい水圧を示している. そして, しだいに第 2 空隙から第 1 空隙へと水が移動し, 最終的 には一重空隙モデルの結果より少し低い水圧で平衡状態 になっている.

Fig. 15 は地表面沈下の水平方向分布であるが, 載荷 直後ではFig. 14 にみられるように, 一重空隙モデルの 水圧の方が, 二重空隙モデルの変形への寄与が大きい第 2 空隙の水圧よりも小さいために，沈下量は一重空隙モ デルの方が大きくなっている．逆に圧密終了時には二重 空隙モデルの方が低い水圧をもっているため沈下量は二 重空隙モデルの方が大きくなっている.

Fig. 16 は c-c'断面での側方変位の深さ方向の分布図
である．不飽和部が存在する場合には飽和状態の解析の 結果に比べ, 載荷直後の側方変位は小さくなり, 圧密終 了時には逆に大きくなる傾向がみられる。

また二重空隙モデルと一重空隙モデルの差は飽和解析 ではほとんどみられないが, 飽和一不飽和状態の解析で は載荷直後で，浅部において二重空隙モデルの方が変位 が大きくなっており，圧密終了時には深部になるほど二 重空隙モデルの方が小さい変位を示している．これは二 重空隙モデルの方が, 不飽和部と飽和部での挙動の差を より顐著に表現できることを示している。

以上のように二重空隙モデルと従来の一重空隙モデル とでは, 変位の経時変化, およびその変形形状が若干異 なったものになり，その差は飽和一不飽和状態の方が飽 和状態よりも大きい傾向を示した．特に載荷重が不飽和 部の存在によって深部にまで影響を及ぼさないという， 従来の連続体の解析では表現しにくかった現象が表わさ れたことは地盤の変形挙動の考察のための一助となるも のと思われる.

\section{6. 結 論}

飽和一不飽和両領域からなる地盤の挙動を把握するた めに二重空隙モデルを用いた応力・変形を考虑した浸透 流解析コードを開発し，種々の現象をシミュレートする ことにより，本手法の有効性について検討した．本研究 で得られた知見および結果は以下のように要約できる.

（1）変形を考慮した飽和-不飽和地盤の二重空隙モ デルの支配方程式を誘導した．その結果得られた有限要 素方程式は非対称なマトリックスとなる.

（2）本手法による圧密および飽和一不飽和浸透の数 值計算手法は一次元弾性モデルならびに砂模型実験との 結果の比較から，ほぼ十分な精度でその基本的機能が満 足できるものであることが確認された.

（3）本手法を用いて, 二次圧密挙動を説明するため には, ペッド部分からの排水による变形量を考慮した弾 性定数を設定する必要がある。このような定数の設定に より二次圧密をクリープ挙動として扱う既往の研究以外 の解析手法が提案されることになり, 現象解明の手がか りが得られるものと期待される.

（4）本手法は岩盤中のように水圧分布が不連続とな るような場合にも適応でき，通常の連続体モデルでは表 現できない現象も再現できる可能性を有している.

（5）従来の圧密解析手法との差は不飽和部が存在す るときに大きくなり, 不飽和部の全体の変形に与える影 響がより顕著に表わされ，これについても今後実測との 比較や検証を重ねることにより，地盤挙動の解明の一助 となることが期待できる. 


\section{7. おわりに}

本研究を遂行するにあたり始終適切なるご指導を頂い た京都大学 足立紀尚教授, ならびに有効なご意見を頂 いた福井大学 荒井克彦助教授と岡山大学 西垣 誠助教 授に対し深甚の感謝の意をここに表します.

\section{参 考 文 献}

1) Sandu, R. S. and Wilson, E. L. : Finite element analysis of seepage in elastic media, J. Eng. Mech. Div. ASCE, EM3, pp. 641 652, 1969.

2) Christian, J. T. and Boehmer, J.W. : Plane strain consolidation by finite elements, J. Soil Mech. and Foundation Div. ASCE, SM4, pp. 1435 1457, 1970.

3) Oda, M. and Hatsuyama, M. : Permeability tensor for jointed rock masses, Proc. of the Int. Symp. on Fundamentals of Rock Joints, pp. 303 312, Bjorkiden, 1985.

4) Long, J. C. S., Remer, J. S., Wilson, C. R. and Witherspoon, P. A. : Porous media equivalents for networks of discontinuous fractures, Water Resources Research 18, No. 3, pp. $645 \sim 658,1982$.

5) Noorishad, T.N., Witherspoon, P.A. and Brekke, T. L. : A method for coupled stress and flow analysis of fractured rock masses, Geotechnical Engineering publication No.71-6, University of California, Berkeley, 1971.

6）大西有三 ·津宏康 : 有限要素法による不連続性体の応 力・変形・浸透流解析, 土木学会論文報告集, No. 322 , pp. $111 \sim 120,1982$

7）大西有三・鍵本広之・西野賢治：岩盤節理情報の処理と その浸透流解析への適用について, 土木学会論文報告集, No. 376, pp. 241 248, 1986.

8) Kawai, T. : New element models in discrete structural analysis, J. Soc. Naval Arch. Japan, Vol. 141, pp. 174 $\sim 180$.
9) Cundall, P. A. : A computer model for simulating prog ressive, large scale movement in block rock systems, Proc. Int. Symp. Rock Fracture, ISRM, Nancy, 1971.

10) Barenblatt, G. I., Zheltov, Iu. P. and Kochika, I. N. : Basic concepts in the theory of seepage of homogeneous liquids in fissured rocks (strata), PMM, Vol.24, 852, pp. 1286 1303, 1960.

11) Huyakorn, P.S., Lester, B.H. and Faust, C. R. : Finite element techniques for modeling groundwater flow in fractured aquifers, Water Resources Research, Vol. 19, No.1019 1035, 1983.

12) Warren, J.E. and Root, P. J. : The behavior of natural ly fractured reservoirs, Soc. of Petroleum Engineers Journal, pp. 245 255, 1963.

13) Sato, K., Shimizu, T. and Itou, Y. : Fundamental study on permeability and dispersion in double porosity rock masses, Fifth International Conference on Numerical Methods in Geomechanics, Nagoya, pp. $657 \sim 664$, 1985.

14) Duguid, J. O. and Lee, P.C.Y. : Flow in fractured porous media, Research Report No.73-WR-1, Princeton University, 1973.

15) Wilson, R. K. and Ainfantis, E. C. : On the Theory of Consolidation with Double Porosity, Int. J. Engng. Sci. Vol. 20, No. 9, pp. 1009 1035, 1982.

16) Nur, A. and Byerlee, J.D. : An exact effective stress law for elastic deformation of rock with fluids, J.G. R. , Vol. 76, No. 26, pp. 6414 6419, 1971.

17）赤井浩一・宇野尚雄：土中の準一次元非定常浸透流に関 する研究, 土木学会論文報告集, No. 127, pp. 14 22, 1966 .

18）嘉門雅史：土の物理学一土質工学の基礎一, pp. 84 86, 森北出版, 1979.

19）荒井克彦 - 渡辺知幸 - 田行啓一：多次元圧密数値解析手 法の比較, 土質工学会論文報告集, Vol. 23, No. 3, pp. 189 195, 1983.

（1987.7.24 • 受付） 